\title{
ELIMINATION OF ADHESIVE IMPURITIES OF THE RECOVERED PAPER IN FLOTATION PROCESS
}

\author{
Vladimír Kuña, Jozef Balberčák, ŠTefan Boháček \\ Pulp And Paper Research Institute \\ SLOVAKIA \\ VLAdimíR IhnÁt \\ Slovak Forest Products Research Institute \\ Slovakia \\ (Received May 2020)
}

\begin{abstract}
The article presents results of the elimination of sticky impurities from recovered paper in laboratory flotation of three pulp suspensions with different whiteness, obtained directly from the production line before entering flotation. A combination of commercial agents releasing undesirable substances from recovered paper and means for regulation and stabilization of froth and modified micronized bentonit was used. In the flotation purification of pulp suspension with a whiteness of 53\%, the combination of Prodeink Extra, Prodeink AS10 and Hydrocol OT reduced the macrostickies content by $58 \%$, the ash content decreased from $18.5 \%$ to $4.5 \%$, the whiteness increased from $53 \%$ to $56.4 \%$ and the residual color content was reduced from $385 \mathrm{ppm}$ to $294 \mathrm{ppm}$. The pulp suspension with a whiteness of $64 \%$ showed a reduction in the content of macrostickies by $66 \%$, a reduction in the ash content by $23.2 \%$, an increase in whiteness by $1.4 \%$ and a reduction in the residual color content from $245 \mathrm{ppm}$ to $194 \mathrm{ppm}$. The pulp suspension with a whiteness of $68.3 \%$ showed a decrease in the content of macrostickies by $58.1 \%$, the ash content decreased from $35.7 \%$ to $6.3 \%$, the whiteness increased by $1.1 \%$ and the content of residual color decreased from $157 \mathrm{ppm}$ to $117 \mathrm{ppm}$.
\end{abstract}

KEYWORDS: Macrostickies, flotation, bentonit, whiteness, residual color, ash content, recovered paper, pulp suspension. 


\section{INTRODUCTION}

New environmental challenges arise in paper industry in recent years and new solutions must be applied, as: retention systems (Kuňa et al. 2016, Mayr et al. 2017), decarbonization (Griffin 2018) and heat recovery systems (Pažitný et al. 2015, 2017), upgraded alkaline cooking processes (Balberčák et al. 2017, 2018), processing of wasted materials (Ihnát et al. 2020, Mašura et al. 2019), etc. The use of recycled fibers has been growing rapidly. Methods of their reuse are also developing (Russ et al. 2013) but they are difficult to put into practice.

In waste paper processing, handling processes of recycled fiber are more complex than the primary fiber processing because waste paper consists of a mixture of different types of fibers or types of paper. Another reason is the presence of pollutants and harmful substances that can contribute to the formation of sticky impurities (Pulz 2000). In order to meet the quality requirements, the pollutants must be removed. The term "purity" is commonly used with respect to optical, chemical, colloidal, microbiological and processing aspects (Holik 2000). Impurities and contaminants are gradually removed using various separation criteria, such as particle size, shape and deformability, density and surface properties of particles. Sequence of operations depends mainly on properties of the raw material and the required properties of the final product (Engstrand and Johansson 2009). In processing of recovered paper, there are two main ways of handling stickies: removal and/or elimination of stickies in the process of sorting, cleaning, flotation, and bleaching (Sarja et al. 2007, Kuňa et al. 2018) and prevention against deposit formation through dispersion, fixation and stickiness removal

\section{Flotation}

Flotation is one way of separating undesirable parts from waste paper. Numerous approaches which define usable flotation models are defined in the literature. Mixed models of the flotation process try to combine the ideas used in the so-called chemical kinetic models with probabilistic models. One generally accepted model describes the ability of a dye to float, as the change in a dye particle per unit time in a given volume. Such a change depends on the number of collisions between the particle and the bubble in a unit volume per unit time (represented by $z_{c}, n_{p}, n_{b}$, where $z_{c}$ is the rate constant, and $n_{p}$ and $n_{b}$ are numbers of parts and bubbles), and on the already mentioned individual probabilities of interaction $\mathrm{P}_{(\mathrm{C})}, \mathrm{P}_{(\mathrm{A})}$, and $\mathrm{P}_{(\mathrm{R})}$ :

$$
\mathrm{dn}_{\mathrm{p}} / \mathrm{dt}=-\mathrm{z}_{\mathrm{c}} \mathrm{n}_{\mathrm{p}} \mathrm{n}_{\mathrm{b}} \mathrm{P}_{(\mathrm{C})} \mathrm{P}_{(\mathrm{A})} \mathrm{P}_{(\mathrm{R})} \quad(-)
$$

where: $\mathrm{P}_{(\mathrm{C})}$ depends on particle and bubble size as well as on hydrodynamic conditions; $\mathrm{P}_{(\mathrm{A})}$ depends on the ratio of colored particle and bubble size, hydrophobicity and contact time; and $\mathrm{P}_{(\mathrm{R})}$ depends on particle weight, contact angle, consistency and flow hydrodynamics.

Efficiency of the flotation process is depended on the surface and colloidal chemistry of the system, as well as on the types of equipment used for air dispersion, mixing and foam separation.

\section{Flotation in deinking process}

In flotation, a large range of particles is distributed based on their surface properties (Amand 1997, Engstrand 2005). Flotation provides a high fiber yield but poor physical properties of the fiber due to the fines content of the fibers (Shammas 2010). During flotation, air is introduced into the low consistency pulp $(0.8 \%-1.5 \%)$ and the hydrophobic particles 
are brought to the top surface after connection to the air bubbles. The pigment-containing froth that has formed in the process is mechanically removed at the top of the flotation cell, by overflow or vacuum (Lassus 2000). As mentioned, flotation is based on the surface properties of the particles. It removes larger hydrophobic particles as opposed to washing, which removes hydrophilic particles.

Several partial surface chemical processes take place during flotation decolorization. The separation of the ink from the fibers, its agglomeration, flotation and foaming are the main steps. Re-bonding of the ink to the fiber is undesirable, but it occurs and is particularly a problem for water-based inks. Agglomeration of paint particles is necessary to achieve flotation because small particles do not bind to bubbles due to hydrodynamic forces. Ability of moving of the small particles is too low and these will follow the flow line around the bubble, while the larger particles collide with it and, under favorable conditions, interact and bond with each other. Collectors, often calcium fatty acid soaps, are used to achieve agglomeration and further improve the chemical interactions between the paint particles and the air bubbles (Engstrand 2005).

Theoretically, flotation should contribute to the efficient removal of micro stickies, due to their hydrophobicity, which facilitates the attachment of sticky particles to air bubbles in a manner similar to paint particles. In addition, unwanted particles are removed in the size range $(10-100 \mu \mathrm{m})$ due to sorting (Engstrand 2005). Amount of $81 \%$ of the micro stickies are removed in the first flotation stage. Post-flotation is able to remove both macro and micro stickies (Lassus 2000, Delagoutte 2008).

Most micro stickies that have been introduced into the process in the sorting step after dispersion are removed in post-flotation (Delagoutte 2008). However, certain conditions during flotation may result in reduction of hydrophobicity of the adhesive particles, leading to lower separation efficiency. This may be due to the time dependence of the surface tension of the adhesive particles, which leads to a reduction of surface tension of the stickies after the addition of the chemicals used in the decolorization in the flotation stage. Another reason may be the adsorption of surfactants on the surface of stickies (Holik 2000). Poor removal of stickies in a favorable size range can also occur due to the disk structure of adherent particles that are not removed by air bubbles (Holik 2000).

\section{MATERIAL AND METHODS}

Three suspensions of pulp (VL5, VL1 and VL0) were prepared for combinations of three chemicals (Prodeink Extra, Prodeink AS10 a Hydrocol OT/Bentonit 4). Chemical charges (kg.t $\mathrm{t}^{-1}$ ) are shown in Tabs. 1-3. Composition of recovered paper of the suspensions was: (1) VL5 suspension $-92.5 \%$ mix of newspapers and magazines $+7.5 \%$ broke from paper machine, (2) VL1 suspension $-13 \%$ mix of newspapers and magazines $+79.5 \%$ white office waste $+7.5 \%$ broke from paper machine, and (3) VL0 suspension $-2,5 \%$ mix of newspapers and magazines $+90 \%$ white office waste $+7,5 \%$ broke from paper machine. Two mixtures of surfactants and two types of bentonites were used for laboratory flotation as: (a) Prodeink Extra (Makokem d.o.o., Zagreb, Croatia) - a mixture of surfactants to release unwanted substances from the recovered paper, (b) Prodeink AS10 (Makokem d.o.o., Zagreb, Croatia) -a mixture of surfactants to control the froth during flotation, (c) Hydrocol OT (HOT) (Süd Chemie AG, Moosburg, Germany) - alkalized micronized bentonit with an average particle size of $4 \mu \mathrm{m}$, and (d) Bentonit 4(B4) alkalized micronized bentonit with an average particle size of $6 \mu \mathrm{m}$. 


\section{Laboratory flotation}

Laboratory flotation tests were performed in the flotation cell shown in Fig. 1, according to the procedure below. The basic suspensions, at a concentration of $1.2 \%$, were homogenized by stirring for $1 \mathrm{~min}$. Chemical 1 (Prodeink EXTRA) was added to the homogenized suspension. The sample was mixed and the chemical was allowed to act for $30 \mathrm{~min}$. The required amount of chemical 2 (Prodeink AS10) was added. The sample was mixed again and the chemical was allowed to act for $10 \mathrm{~min}$. The required amount of chemical 3 (Hydrocol OT) was added, after mixing the chemical was allowed to act for $10 \mathrm{~min}$. A total of 2.6 liters of sample was taken and transferred to a flotation device. After starting the flotation device, in addition to mixing, the air supply was switched on. The amount of air was adjusted to bubble gently. The floated froth was removed continuously. After 10 min of flotation, both stirring and air supply were stopped. Laboratory sheets were made from the floated suspension, from which the required parameters were determined.

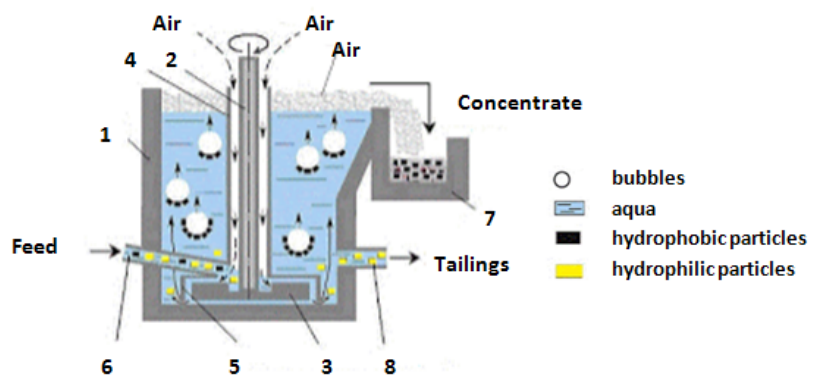

Fig. 1: Laboratory flotation machine (Petrowskaya 2007): (1) flotation machine, (2) support, (3) rotor, (4) air inlet, (5) stator, (6) feed inlet, (7) froth discharging area, (8) release of tailings.

\section{Determination of stickies}

For the determination of sticky impurities, a sample of $30 \mathrm{~g}$ was used, which was sorted in a laboratory sorter Sommerville on a $150 \mu \mathrm{m}$ slice plate under constant rinsing. Sorting time was $20 \mathrm{~min}$. The material captured on the sorting plate was quantitatively transferred using a Rapid-Kothen sheet-cutter to a filter paper of $220 \mathrm{~mm}$ diameter so that it is distributed evenly over its entire surface. Filter paper with the sorted substance was allowed to dry freely in the air. Sheets of sorted and dried material were placed between two clean filter sheets with a diameter of $220 \mathrm{~mm}$. They were pressed in a press with heated plates at a temperature of $160^{\circ} \mathrm{C}$ and a pressure of $2.5 \mathrm{MPa}$ for $4 \mathrm{~min}$. After pressing and cooling, the sheets were separated from each other and impurities greater than $0.1 \mathrm{~mm}^{2}$ are counted, which were compressed or bonded to the filter paper. Evaluation of the number of sticky impurities is given in $\mathrm{pcs}^{\mathrm{kg}} \mathrm{kg}^{-1}$ substances.

\section{Determination of ash content, whiteness and residual color in pulp suspensions}

Whiteness and residual color were determined according to STN ISO 2470-1, ISO 3688, resp. Determination of ash content in pulp suspensions was performed according to ISO 1762. 


\section{RESULTS AND DISCUSSION}

During laboratory tests of flotation cleaning of recovered paper we applied a combination of three types of chemicals in order to improve its paper forming properties. The agent for releasing undesirable substances from the recovered paper Prodeink Extra, the agent for agglomerating undesirable substances and improving the sorting efficiency of Hydrocol OT, bentonit B4 and the agent for regulating the froth during flotation Prodeink AS.

Laboratory tests were performed on three types of pulp suspensions: the suspension VL5 with whiteness of 53\% prepared from dark types of recovered paper, the suspension VL1 with whiteness of $64 \%$ prepared from mix of dark and bright types of recovered paper and the suspension VL0 with whiteness of $68 \%$ prepared from bright types of recovered paper. In addition to determining the content of macrostickies, the ash content, whiteness and residual color in individual water bodies was determined as part of the evaluation of the quality of flotation procedures. The results of laboratory research, applications of flotation in the elimination of macrostickies, are presented in Tabs. 1-3 and in Figs. 2-5

Tab.1: The effect of flotation on the properties of VL5 suspension with whiteness 53\%.

\begin{tabular}{|c|c|c|c|c|c|c|c|}
\hline Sample & $\underset{(\text { pg.t }}{\text { Pro Extra }}$ & $\underset{\left.\text { (kg.t }{ }^{-1}\right)}{\text { Pro AS10 }}$ & $\underset{\left(\mathrm{kg} \cdot \mathrm{t}^{-1}\right)}{\text { Bentonit }}$ & $\begin{array}{c}\text { Macrostickies } \\
\text { (pc per kg) }\end{array}$ & Ash (\%) & $\begin{array}{c}\text { Whiteness ISO } \\
(\%)\end{array}$ & $\begin{array}{l}\text { Residual color } \\
\text { (ppm) }\end{array}$ \\
\hline Primary* & 0 & 0 & 0 & 450 & 18.5 & 53 & 385 \\
\hline F0 & 0 & 0 & 0 & 428 & 8.3 & 54.8 & 369 \\
\hline $\mathrm{F} 1$ & 2 & 0 & 0 & 412 & 5.1 & 55.2 & 351 \\
\hline $\mathrm{F} 2$ & 2 & 0.5 & 0 & 390 & 4.8 & 56 & 318 \\
\hline F3 & 2 & 1 & 0 & 316 & 4.6 & 56.1 & 306 \\
\hline F4 & 2 & 0.5 & 2 & 190 & 4.5 & 56.4 & 294 \\
\hline F5 & 1 & 0 & 0 & 420 & 5.6 & 54.8 & 369 \\
\hline F6 & 1 & 0.5 & 0 & 398 & 4.8 & 55.5 & 345 \\
\hline F7 & 1 & 1 & 0 & 326 & 4.6 & 56.3 & 307 \\
\hline F8 & 1 & 0.5 & 2 & 299 & 4.4 & 56 & 313 \\
\hline F9 & 1 & 0.5 & 4 & 230 & 4.6 & 56.5 & 287 \\
\hline F10 & 1 & 1 & 2 & 285 & 4.7 & 56.3 & 295 \\
\hline F11 & 1 & 1 & 4 & 224 & 5.2 & 55.8 & 321 \\
\hline
\end{tabular}

* The sample without flotation.

Tab.2: The effect of flotation on the properties of VL1 suspension with whiteness 64\%.

\begin{tabular}{|c|c|c|c|c|c|c|c|}
\hline Sample & $\begin{array}{c}\text { Pro Extra } \\
\left(\text { kg.t } t^{-1}\right)\end{array}$ & $\begin{array}{c}\text { Pro AS10 } \\
\left.\text { (kg.t }{ }^{-1}\right)\end{array}$ & $\underset{\left(\text { kg.t }{ }^{-1}\right)}{\text { Bentonit }}$ & $\begin{array}{l}\text { Macrostickies (pcs } \\
\text { per kg) }\end{array}$ & $\operatorname{Ash}(\%)$ & $\begin{array}{c}\text { Whiteness ISO } \\
\text { (\%) }\end{array}$ & $\begin{array}{l}\text { Residual color } \\
\text { (ppm) }\end{array}$ \\
\hline Primary* & 0 & 0 & 0 & 900 & 29.3 & 64.0 & 245 \\
\hline F0 & 1 & 0 & 0 & 860 & 7.9 & 64.1 & 242 \\
\hline F1 & 1 & 0.5 & 0 & 620 & 7.3 & 64.5 & 227 \\
\hline $\mathrm{F} 2$ & 1 & 1 & 0 & 550 & 6.9 & 64.6 & 225 \\
\hline F3 & 1 & 0.5 & $2 \mathrm{HOT}$ & 445 & 6.1 & 64.6 & 223 \\
\hline F4 & 1 & 0.5 & $4 \mathrm{HOT}$ & 500 & 6.2 & 65.3 & 225 \\
\hline F5 & 1 & 1 & $2 \mathrm{HOT}$ & 305 & 6.1 & 65.2 & 194 \\
\hline F6 & 1 & 1 & $4 \mathrm{HOT}$ & 319 & 6.2 & 65.2 & 197 \\
\hline
\end{tabular}




\begin{tabular}{|c|c|c|c|c|c|c|c|}
\hline F7 & 1 & 0.5 & 2B4 & 483 & 6.1 & 64.7 & 223 \\
\hline F8 & 1 & 0.5 & $4 \mathrm{~B} 4$ & 480 & 6.4 & 64.7 & 224 \\
\hline F9 & 1 & 1 & 2B4 & 310 & 6.2 & 65.1 & 195 \\
\hline F10 & 1 & 1 & $4 \mathrm{~B} 4$ & 318 & 6.3 & 65.0 & 198 \\
\hline
\end{tabular}

* The sample without flotation.

Tab.3: The effect of flotation on the properties of VLO suspension with whiteness $68.3 \%$.

\begin{tabular}{|c|c|c|c|c|c|c|c|}
\hline Sample & $\underset{\left.\text { (kg.t }^{-1}\right)}{\text { Pro Extra }}$ & $\underset{\left(\mathrm{kg}^{-\mathrm{t}^{-1}}\right)}{\text { Pro AS10 }}$ & $\begin{array}{c}\text { Bentonit } \\
\left(\mathrm{kg} \cdot \mathrm{t}^{-1}\right)\end{array}$ & $\begin{array}{l}\text { Macrostickies } \\
\text { (pcs per kg) }\end{array}$ & $\begin{array}{c}\text { Ash } \\
(\%)\end{array}$ & $\begin{array}{c}\text { Whiteness } \\
\text { ISO (\%) }\end{array}$ & $\begin{array}{l}\text { Residual color } \\
\text { (ppm) }\end{array}$ \\
\hline Primary* & 0 & 0 & 0 & 1230 & 35.7 & 68.3 & 157 \\
\hline F0 & 1 & 0 & 0 & 1180 & 8.5 & 68.5 & 153 \\
\hline $\mathrm{F} 1$ & 1 & 0.5 & 0 & 845 & 7.3 & 68.8 & 137 \\
\hline $\mathrm{F} 2$ & 1 & 1 & 0 & 720 & 6.9 & 69.0 & 132 \\
\hline F3 & 1 & 0.5 & $2 \mathrm{HOT}$ & 680 & 6.3 & 69.3 & 127 \\
\hline $\mathrm{F} 4$ & 1 & 0.5 & $4 \mathrm{HOT}$ & 680 & 6.2 & 69.3 & 130 \\
\hline F5 & 1 & 1 & $2 \mathrm{HOT}$ & 520 & 6.3 & 69.5 & 117 \\
\hline F6 & 1 & 1 & 4HOT & 515 & 6.3 & 69.4 & 117 \\
\hline F7 & 1 & 0.5 & $2 \mathrm{~B} 4$ & 695 & 6.3 & 69.2 & 120 \\
\hline F8 & 1 & 0.5 & $4 \mathrm{~B} 4$ & 680 & 6.4 & 69.2 & 121 \\
\hline F9 & 1 & 1 & $2 \mathrm{~B} 4$ & 540 & 6.1 & 69.2 & 119 \\
\hline F10 & 1 & 1 & $4 \mathrm{~B} 4$ & 530 & 6.2 & 69.2 & 120 \\
\hline
\end{tabular}

* The sample without flotation.

\section{The effect of flotation procedures on the content of macrostickies}

The best results of the elimination of macrostickies on the VL5 suspension were obtained by the F4 flotation procedure (Tab. 1). By applying this procedure, the content of macrostickies was reduced from 450 to 190 pcs.kg-1, which represents a decrease by 58\%. For the VL1 suspension, the best results in the elimination of macrostickies were obtained by the $\mathrm{F} 5$ procedure (Tab. 2). With this combination of chemicals a reduction in the content of macrostickies by $66 \%$ (decrease from 900 pcs. $\mathrm{kg}^{-1}$ to 305 pcs.kg-1) was achieved. With the VL0 suspension, the best macrostickies elimination results were obtained with the F6 combination (Tab. 3). This combination of chemicals reduced the content of macrostickies by $58.1 \%$ (decrease from 1230 pcs. kg-1 to 515 pcs. $\mathrm{kg}^{-1}$ ). The results obtained are consistent with the results (Lassus 2000 and Delagoutte 2008), which achieved flotation efficiency of up to $81 \%$ in eliminating macrostickies.

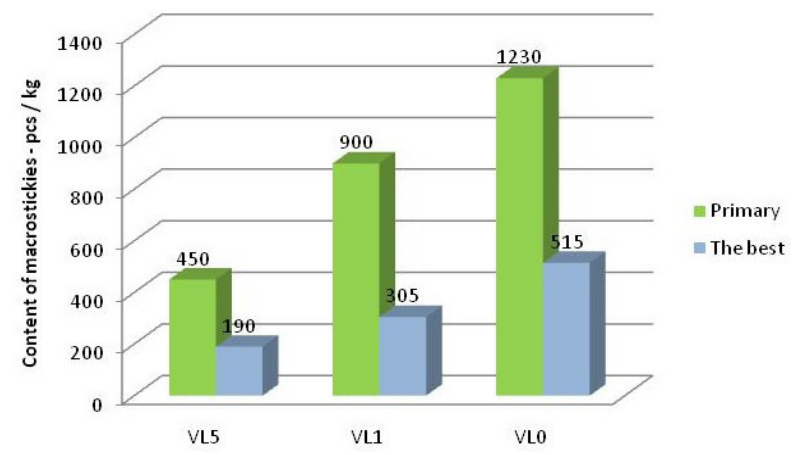

Fig. 2: The effect of flotation procedures on the content of macrostickies. 


\section{The effect of flotation procedures on whiteness}

By applying the best working procedures for individual types of suspensions (Tabs. 1-3), an increase of whiteness by $3.4 \%$ was achieved for the VL5 suspension, by $1.3 \%$ for the VL1 suspension, and by $1.1 \%$ in the VL0 suspension, as stated and (Fig. 3). The optical properties (whiteness or yellowness) of recycled paper are the focus of several authors (Jurič et al. 2018, Tutuş et al. 2013). Bleaching agents are present in suspensions for this purpose.

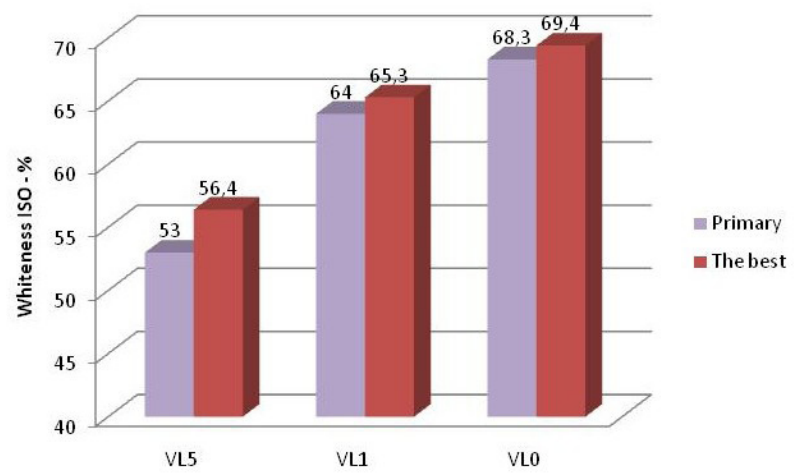

Fig. 3: Effect of flotation procedures on whiteness.

\section{The effect of flotation procedures on ash content}

The ash in pulp consists of several different components, which can be mineral substances from the wood raw material, metallic residues from pipes and machinery parts or residues from chemicals used in the pulping process. Often the ash content is related to the filler content (e.g. calcium carbonate, clay) in pulp (Kirilova and Lindberg 2012). The effect of flotation on ash content in the suspensions are shown in Fig. 4. Using the best working procedures according to Tabs.1-3, a reduction of the ash content was achieved for the VL5 suspension by $14.0 \%$, for the VL1 suspension by $23.2 \%$, and for the VL0 suspension by $29.4 \%$ (Fig. 4).

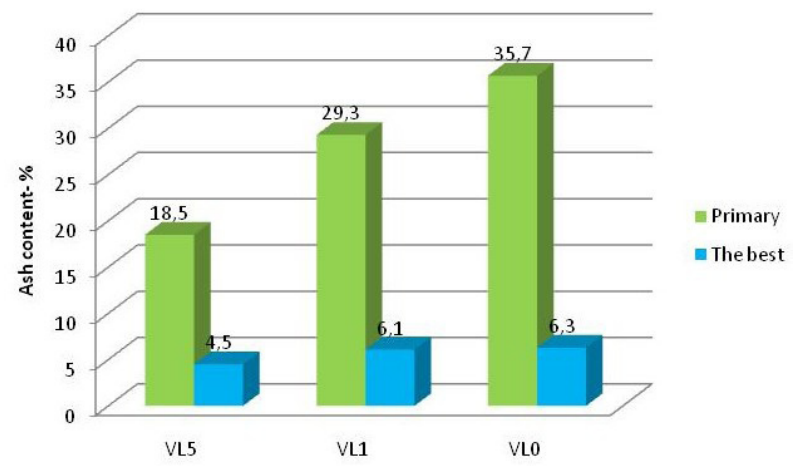

Fig. 4: The effect of flotation procedures on ash content.

\section{The effect of flotation procedures on residual color content}

The best working practices for individual suspensions (Tabs.1-3) allowed to reduce the residual color content from $385 \mathrm{ppm}$ to $294 \mathrm{ppm}$ for VL5 suspension, from $245 \mathrm{ppm}$ to $194 \mathrm{ppm}$ 
for VL1 suspension and from 157 ppm to 117 ppm for VL0 suspension, as it is shown in (Fig. 5). According to some authors, it is possible to achieve up to $50 \%$ efficiency in flotation in reducing residual color (Xiansheng et al. 1998, Imamoglu et al. 2013).

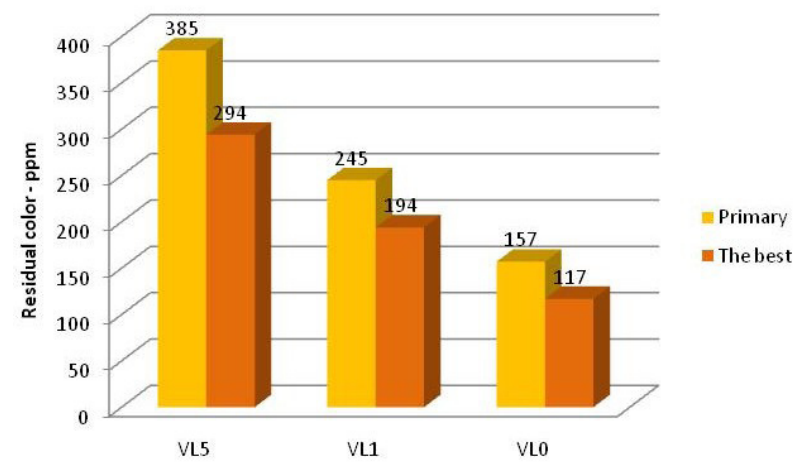

Fig. 5: The effect of flotation procedures on residual color content.

\section{CONCLUSIONS}

By a suitable combination of paper agents in the processing of recovered paper, it is possible to increase the efficiency of flotation while eliminating macrostickies. The combination of Prodeink Extra intended to improve the release of undesirable substances from recovered paper, Hydrocol OT intended for agglomeration of stickies and Prodeink AS10 intended for stabilization of flotation froth, a reduction of macrostickies contents in pulp suspensions VL5 by $58 \%$, in VL1 by $66 \%$ and in VL0 by $58.1 \%$ was achieved. The application of suitable chemicals has increased the flotation efficiency in reducing the ash content, increasing the whiteness of pulp and reducing the residual color content, as well. Better quality of pulp suspension after flotation creates better conditions at its quality in a line of recovered paper processing which has a positive effect on paper production as a whole.

\section{ACKNOWLEDGMENT}

This work was supported by the Slovak Research and Development Agency under contract No. APVV-16-0409

\section{REFERENCES}

1. Amand, F.J.S., 1997: Hydrodynamics of flotation' experimental studies and theoretical analysis. TAPPI Recycling Symposium, TAPPI Press, Atlanta, GA, 219 pp.

2. Balbercak, J., Bohacek, S., Medo, P., Ihnat, V., Lubke, H., 2017: Chemical processing of waste wood based agglomerates Part I: Evaluation of properties of fluting liners made of semichemical pulp obtained by a mildly alkaline sulphur-free cooking process. Wood Research 62(5): 715-726. 
3. Balbercak, J., Bohacek, S., Pazitny, A., Ihnat, V., Lubke, H., 2018: Chemical processing of waste wood based agglomerates part II: Evaluation of properties of fluting liners made of semichemical pulp obtained by an alkaline cooking process. Wood Research 63(1): 35-44.

4. Blanco, A., Miranda, R., Negro, C., Garcia-Suarez, C., Garcia-Prol, M., Sanchez, A., 2007: Full characterization of stickies in a newsprint mill: the need for a complementary approach. Tappi Journal 6(1):19-25.

5. Delagoutte, T., 2008: Stickies characterization along the deinking lines of the SCA tissue mills. Grenoble, 68 pp.

6. Engstrand, P., Johansson, B., 2009: Paper recycling. In: Pulping Chemistry and Technology (ed. Ek, M., Gellerstedt, G., Henriksson, G.)., Walter de Gruyter, Berlin, Pp 391-427.

7. Griffin, P.W., Hammond, G.P., Norman, J.B., 2018: Industrial decarbonisation of the pulp and paper sector: A UK perspective. Applied Thermal Engineering 134: 152-162.

8. Holik, H., 2000: Unit operations and equipment in recycled fiber processing. In: Recycled fiber and deinking (ed. Göttsching, L., Pakarinen, H.)., Fapet Oy. Helsinki, Finland, Pp 91-201.

9. Ihnát, V., Lübke, H., Balberčák, J., Kuňa, V., 2020: Size reduction downcycling of waste wood. Review. Wood Research 65(2): 205-220.

10. Jurič, I., Novaković, D., Kašiković, N., Dedijer, S., Milić, N., Vasić, J., 2018: Influence of optical paper properties of recycled and non-recycled papers for digital printing on colour reproduction. In: 8th Conference on Information and Graphic Arts Technology, Slovenia, 7-8 June., University of Ljubljana, Pp 207-213.

11. Kirilova, S., Lindberg, S., 2012: Sticky deposits in a tissue manufacturing process. Master of Science Thesis. Chalmers University of technology, Göteborg, 74 p.

12. Kuňa, V., Balberčák, J., Pažitný, A., Russ, A., Boháček, Š., 2018: Tackiness reducing of stickies surfaces by inorganic agents and organic polymers. Wood Research 63(6): 1013-1019.

13. Kuňa, V., Balberčák, Opálená, E., Pažitný, A., Russ, A., Schwartz, J., 2016: The effect of multi-component retention systems on the properties of the paper suspensions. Wood Research 61(5): 767-776.

14. Lassus, A., 2000: Recycled fiber and deinking. In: Recycled fiber and deinking (ed. Göttsching, L., Pakarinen, H.). Pp 241-264, Fapet Oy. Helsinki, Finland.

15. Mayr, M., Eckhart, R., Winter, H., Bauer, W., 2017: A novel approach to determining the contribution of the fiber and fines fraction to the water retention value (WRV) of chemical and mechanical pulps. Cellulose 24: 3029-3036.

16. Mašura, V., Balberčák, J., Kuňa, V., Mikulášik, R., 2019: Reaction phases of the wood constituents' degradation during Kraft cooking of spruce chips. Wood Research 64(6): 975-985.

17. Petrovskaya, N., 2007: Fundamentals of the theory of flotation. Libro, 192 pp.

18. Pažitný, A., Boháček, Š., Medo, P., Balberčák, J., 2015: Application of innovative heat recovery unit in paper industry with potential utilization in wood-processing and furniture industry. Wood Research 60 (1): 101-112.

19. Pažitný, A., Boháček, Š., Medo, P., Balberčák, J., Schwartz, J., Kuňa, V., Ihnát, V., 2017: Possibilities of removing condensate from a heat recovery unit utilizable in paper industry. Wood Research 62 (2): 273-282.

20. Putz, J., 2000: Stickies in recycled fiber pulp. In: Recycled fiber and deinking (ed. Göttsching, L., Pakarinen, H.)., Fapet Oy. Helsinki, Finland, Pp 441-498. 
21. Russ, A., Schwartz, J., Boháček, Š., Lübke, H., Ihnát, V., Pažitný, A., 2013: Reuse of old corrugated cardboard in constructional and thermal insulating boards.Wood Research 58(3): 505-510.

22. Shammas, N., Wang L.K., Selke, W.A., 2010: Completely closed water systems in paper mills. In: Volume 12. Flotation Technology (ed. Wang, L.K., Shammas, N.K., Selke, W.A., Aulenbach, D.B.)., Humana Press. New York, Pp 401-427.

23. Sarja, T., 2007: Measurements, nature and removal of stickies from deinked pulp. Faculty of Technology of the University of Oulu, Finland, $82 \mathrm{pp}$.

24. Tutuş, A., Demir, N., Çiçekler, M., 2013: Evaluation of waste papers in producing newspaper. In: International Caucasian Forestry Symposium, Artvin, Turkey, 24-26 October. Pp 894-897, Artvin Coruh University.

25. Xiansheng, N, Miller, J.D., Yeboah, Y.D., 1998: The effect of ink types and printing processes on flotation deinking efficiency of wastepaper recycling. Environmental Engineering and Policy 1(1): 47-58.

26. Imamoglu, S., Karademir, A., Pesman, E., 2013: Effect of flotation deinking on the removal of main colors of oil-based inks from uncoated and coated office papers. Bioresources 8(1): $45-58$.

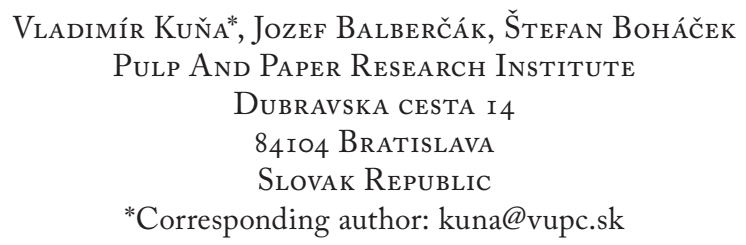

Vladimir Ihnát

Slovak Forest Products Research Institute

Dubravska CEsta I 4

84io4 Bratislava

Slovak Republic 